\title{
Foreword and Acknowledgements
}

Writing is a solitary occupation, but writing a biography inevitably brings the writer into contact with a great many people, and I have been extremely fortunate in the help that I have been given: Wallace inspires affection and admiration in successive generations. My first, and greatest, thanks is to Wallace's grandsons, John and Richard Wallace, and their families. They have made their family papers and archives available, in a most generous and unpressured way, given me permission to use material, answered my questions patiently, and offered me encouragement and hospitality in large measures.

Wallace's letters, notebooks and specimens are scattered through the world, and it would be a long journey to visit them all. This makes the assistance of librarians and archivists the more vital, and I am grateful for the prompt and helpful way they have responded to my enquiries. My local library, at Cambridge University, has been most frequently in the firing line, not only because of its Wallace holdings, such as his letters to his agent Stevens and to his friends Charles Darwin and Alfred Newton, but because of the siting there of the Darwin project. It is a nice irony that so many of the key holdings of books in the field, including Wallace's autobiography and published letters, as well as those of Bates and Spruce, are on permanent loan to the project, in service as it were to Darwin, and have to be tracked down and consulted in a special area. One can imagine a wry comment on the subject from Wallace to Professor Poulton. There are, of course, benefits to this arrangement, not least the company and help of the Darwin research team.

I should like in particular to thank the Trustees, curators, librarians, archivists and staff of the following institutions for their assistance, and for permission to quote from material in their keeping: the British Library; 
Cambridge University Library; City of London Record Office; Hertford County Archives; Imperial College, London; Leicester County Archives; the Linnean Society (and especially Gina Douglas); Natural History Museum, London; Neath Public Library; Oxford Museum of Natural History (and especially Stella Brecknell, of the Hope Entomological Collection); Royal Geographical Society; Royal Botanic Gardens, Kew (and especially Lesley Price); Royal Geographical Society; San Jose Public Library; Surrey History Centre; University College, London; Zoological Society, London.

Many others have given me help, advice, information and encouragement, at different stages. I would like to mention specifically George Beccaloni, at the Natural History Museum, who has shared his knowledge and enthusiasm with me; John Beer, for doing some research on my behalf in Boston; Michael Brooke, for ornithological advice; Andrew Carter; John Dickenson, for information on Wallace and Bates and the Royal Geographical Society; Robert Dimsdale, for his knowledge of Hertfordshire, and of vaccination; Robert Francis, who was our guide in Sarawak; David Hanke, for reading and commenting on sections of the text; Walter Henderson; Richard Ironside; Bob Lashmar; Perry O'Donovan, of the Darwin project; Michael Pearson, for drawing several articles to my attention, and for providing me with a typed transcript of Wallace's American journal; Christopher Roper, and Landmark Information Group, Exeter, for making available Ordnance Survey maps and information on Wallace's houses at Gray's, Essex, and Broadstone, Dorset; Sister Rita; Peter Searby; John Webb, of the Thurrock Local History Society; John Wilson, for his generous help; and Christopher Wells, for many conversations and insights. Elizabeth, my wife, as well as organising my trip to Singapore and Sarawak, and acting as photographer on that and many other expeditions, has had to live patiently and, luckily for me, happily with Wallace for a number of years. My editors, Jenny Uglow at Chatto and Windus and Sam Elworthy at Princeton University Press, have been wonderfully supportive, and I would like to thank Jenny Uglow for her suggestions and comments at every stage; these, however painful at the time, invariably led to something better (a true Wallace principle). 
Names: I have usually retained the names used by Wallace in his writing, and indicated the modern equivalent in brackets on the first occasion, for example Barra (Manaos), Gilolo (Halmahera). One exception to this practice is the river Vaupés, where Wallace uses 'Uaupes', a form I struggled with. Spelling on the maps also generally follows Wallace's practice. 


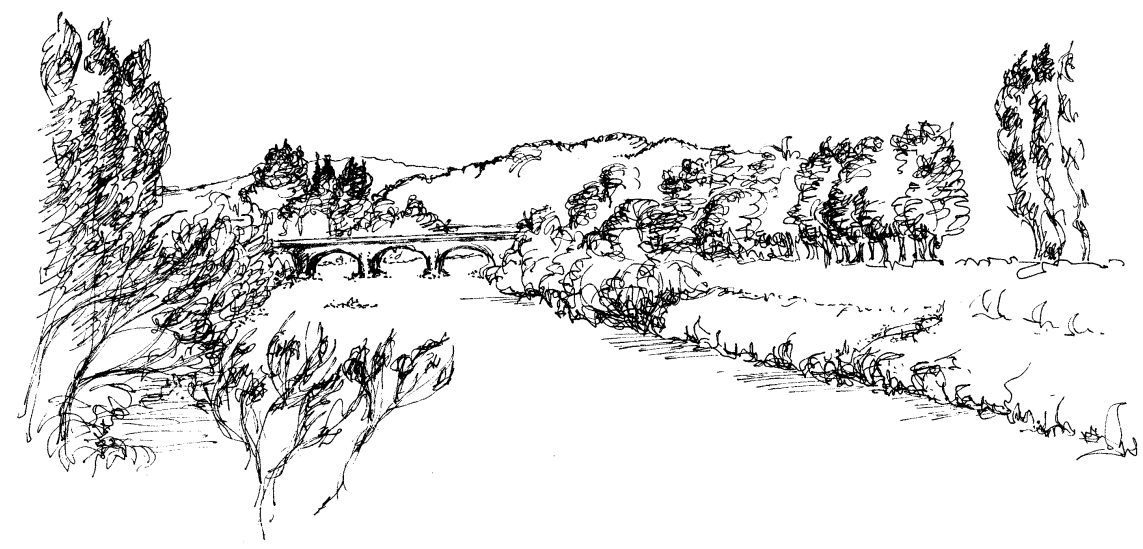

\section{Introduction}

Alfred Russel Wallace wrote to his friend Henry Walter Bates in 1847 after spending a week beetle-hunting with him in Wales,

I begin to feel rather dissatisfied with a mere local collection, little is to be learned by it. I should like to take some one family to study thoroughly, principally with a view to the theory of the origin of species. By that means I am strongly of opinion that some definite results might be arrived at. ${ }^{1}$

He was twenty-four, training himself as a field naturalist, and enjoying a self-administered crash course in scientific theory. Three years earlier, he had been introduced to the wonders of beetles by Bates, and was amazed to discover that there were perhaps a thousand different kinds to be found within ten miles of Leicester. Only one year after writing this letter, in 